\title{
PHYSICO-CHEMICAL STUDIES DURING THE RIPENING OF THE FRUIT OF LYCOPERSICON ESCULENTUM MILL VAR. NAVEEN
}

\author{
Balamurugan S. \\ Botany Wing (DDE), Division of Plant Physiology, Annamalai University, \\ Annamalainagar - 608002, Tamilnadu - India \\ E-mail address: drbalu2011@gmail.com
}

Keywords: Fruit; physico-chemical; TSS; PH

\begin{abstract}
A correlative study on physico-chemical changes during fruit ripening in Lycopersicon esculentum has been carried out. The tomato fruit was collected at its four successive stages viz. 1 . Mature green, 2. Half ripened, 3. 3/4 ${ }^{\text {th }}$ - ripened and 4. Fully ripened for its physico-chemical analysis. The obtained result showed that with advancement of fruit maturation the amount of pigments (total carotenoids, lycopene), total sugars, reducing sugars increase significantly. While that of physio chemical studies of weight of fruit, pulp, peel and volume of fruit decrease gradually. However TSS, titrable acidity, $\mathrm{PH}$, ascorbic acid, tannins as moisture of tomato fruits could be considered as maturity indices to judge the ripening stages of tomato fruits for various value added products preparation.
\end{abstract}

\section{INTRODUCTION}

Lycopersicon esculentum Mill var. Naveen is one of the most important and widely cultivated vegetables in India and according to (FAD, 2001) the annual production of tomato in India was 4,500 MT, there is increasing evidence that diet can play an important role in human health by providing important substances that increase the body defence system against several diseases. Tomato is a major contribution of carotenoids (especially lycopene), phenolics, vitamin $\mathrm{C}$, and small amount of vitamin $\mathrm{E}$ in daily diet (Khachik et al., 2002). Ripening stage of fruit affects physico-chemical parameters of fruit which ultimately affects the quality of processed product prepared from them. Hence, an experiment was undertaken to study the effect of different stages of ripening on physico-chemical parameters of tomato fruits.

\section{MARERIALS AND METHODS}

The present investigation was conducted at the Department of Botany, Annamalai University, Annamalainagar, India during the year 2013.Well matured fruits of uniform medium size of cv. Naveen were collected, washed with tap water and kept in the laboratory at an ambient temperature for ripening. Lycopersicon esculentum fruits of different stages of ripening viz.1. Mature green, 2. Half ripened, 3. 3/4 $4^{\text {th }}$ - ripened and 4. Fully ripened were selected and used for physico-chemical analyses. The experiment was conducted by the following complete randomized design with 4 levels of ripening stage with 5 replications. To study the physico-chemical characteristic, 10 tomato fruits from each ripening stage were randomly selected and examined individually for various physical parameters. The average of 10 fruits has been reported for each physical parameter. For chemical analysis of tomato fruit from different ripening stages was taken for estimating various chemical parameters. Moisture and TSS were estimated by the method decribed by (Anon, 1975). However, reducing sugar, total sugar, titratable acidity, ascorbic acid and tannin content were estimated by the methods described by (Ranganna, 1977). The PH was measured by using standard solutions of PH 4.0 and 7.0 as reference to calibrate. 


\section{RESULTS AND DISCUSSION}

Weight of fruit and peel, weight of pulp, volume of fruit, length and diameter and colour of fruit from mature green stage to fully ripened stage of tomato fruit. The fruit weight ratio showed decreasing trend from mature green stage to fully ripened stage. This decreasing trend obtained during ripening of tomato fruit may be attributed to loss of moisture due to respiration and transpiration during ripening process. The present study of decreasing trends in weight, volume, length and diameter of fruit are supported by (Pawar, 1988) karonda fruit. Minimum weight of peel observed at fully ripened stage $(4.25 \mathrm{~g})$ was the impact loss of maximum moisture from skin. However, increase in gravity of fruits from 1.02 (Mature green stage) to $1.05\left(3 / 4^{\text {th }}-\right.$ ripened stage) during ripening indicated that, the decrease in weight of fruit was lesser than the corresponding decreasing in its volume. Similar observations have been reported by (Joshi et al., 1986) for karonda fruits. The colour of the tomato fruit changed from green (Mature green stage) to red (Fully ripened stage) during ripening (Table $-\mathrm{I}$ ).

It is observed from (Table - II) that, all the chemical parameters studied showed significant difference with respect to ripening stage of fruit, except moisture content of fruit. Total soluble solids total and reducing sugar content of tomato fruit at different stages of ripening increased significantly from Mature green stage $\left(18.0^{\circ}\right.$ Brix, $14.40 \%$ and $\left.8.75 \%\right)$ to $3 / 4^{\text {th }}-$ ripened stage $\left(23.56^{\circ}\right.$ Brix, $17.12 \%$ and $\left.11.08 \%\right)$ with slight decline at Fully ripened stage $\left(22.60{ }^{\circ}\right.$ Brix, $18.20 \%$ and $10.11 \%$ ). An increase in TSS and sugars during ripening process in tomato fruit may probably be due to accumulation of more sugars in the fruit due to hydrolysis of starch and slight decline at fully ripened stage was due to utilization of sugars during respiration process. The results of this investigation are in agreement with the results obtained by (Raut, 1999) in sapota fruit. Decrease in acidity from mature green stage $(10.20 \%)$ to fully ripened stage $(0.9 \%)$ observed during ripening may be attributed to the oxidation of organic acids (Hulme, 1970). The increase in PH from 4.20 to 5.30 during ripening of tomato fruit may be attributed to the decrease in acidity during ripening. Results of the present study are supported by (Paralkar, 1985) in sapota and (Pawar, 1988) in karonda fruit.

An increase in ascorbic acid content in fruit though to be indication that the fruit still in the ripening stage, while a decrease indicates a senescent frit (Esteves et al., 1984). The presence of phenolics in the fruit cells may help to maintain the ascorbic acid content. Ascorbic acid content of tomato fruit decline throughout the ripening process from $12.60 \mathrm{mg} / 100 \mathrm{~g}$ (Fully ripened stage) due to oxidative destruction during ripening (Hulme, 1970). Identical observation during ripening were also reported by (Suryanarayana and Goud., 1984) in sapota fruit. Sharp decrease in tannins was observed during ripening of tomato fruit. This may due to the fact that tannins are hydrolysed into components like sugars, acids and other compounds during ripening and also due to its oxidation by polyphenol oxidase to form colour pigment. Similar results were reported by (Swant, 1989). The moisture content of tomato fruit decreased continuosly from Mature green stage $(60.80 \%)$ to Fully ripened stage $(52.80 \%)$. However, the results were non significant. Decline in moisture of tomato fruit during ripening could be attributed to the loss of moisture through respiration and transpiration. Similar findings were also reported by (Raut, 1999) in sapota fruits.

Table - I Physical parameters of Lycopersicon esculentum during ripening

\begin{tabular}{|l|c|c|c|c|c|c|c|c|}
\hline \multicolumn{1}{|c|}{$\begin{array}{c}\text { Ripening } \\
\text { Stages }\end{array}$} & $\begin{array}{c}\text { Weight } \\
\text { of fruit } \\
\text { (g) }\end{array}$ & $\begin{array}{c}\text { Weight } \\
\text { of peel } \\
\text { (g) }\end{array}$ & $\begin{array}{c}\text { Weight } \\
\text { of pulp } \\
\text { (g) }\end{array}$ & $\begin{array}{c}\text { Volume } \\
\text { of fruit } \\
\text { (ml) }\end{array}$ & $\begin{array}{c}\text { Specific } \\
\text { gravity }\end{array}$ & $\begin{array}{c}\text { Length } \\
\text { of fruit }\end{array}$ & $\begin{array}{c}\text { Diameter } \\
\text { of fruit }\end{array}$ & Fruit colour \\
\hline Mature green & 95.23 & 7.26 & 84.41 & 92.51 & 1.02 & 5.54 & 5.53 & Green \\
\hline Halr- ripened & 92.87 & 8.43 & 81.84 & 88.54 & 1.05 & 5.59 & 5.39 & Greenish yellow \\
\hline $\mathbf{3 / 4 ^ { \text { th } } - \text { ripened }}$ & 85.62 & 8.74 & 73.34 & 78.09 & 1.05 & 5.43 & 5.32 & Yellowish red \\
\hline Fully ripened & 60.66 & 4.25 & 54.28 & 59.32 & 1.02 & 4.85 & 4.78 & Completely red \\
\hline S.Em \pm & 1.65 & 0.39 & 2.18 & 1.41 & 0.01 & 0.25 & 0.19 & - \\
C.D at 1\% & 6.78 & 1.57 & 8.73 & 5.78 & 0.03 & 1.07 & NS & - \\
\hline
\end{tabular}


Table - II Chemical composition of Lycopersicon esculentum during ripening

\begin{tabular}{|c|c|c|c|c|c|c|c|c|}
\hline $\begin{array}{c}\text { Ripening } \\
\text { Stages }\end{array}$ & $\begin{array}{c}\text { T.S.S } \\
\left({ }^{\circ} \text { Brix }\right)\end{array}$ & $\begin{array}{c}\text { Total } \\
\text { sugars } \\
(\%)\end{array}$ & $\begin{array}{c}\text { Reducing } \\
\text { sugars } \\
(\%)\end{array}$ & $\begin{array}{c}\text { Titratable } \\
\text { Acidity } \\
\text { (\%) }\end{array}$ & pH & $\begin{array}{l}\text { Ascorbic } \\
\text { acid } \\
(\mathrm{mg} / \mathbf{1 0 0 g})\end{array}$ & $\begin{array}{c}\text { Tannins } \\
(\%)\end{array}$ & Moisture \\
\hline Mature green & 18.00 & 15.40 & 8.75 & 0.20 & 4020 & 12.60 & 0.45 & 60.80 \\
\hline Halr- ripened & 22.50 & 16.75 & 9.90 & 0.21 & 5.60 & 15.23 & 0.29 & 74.10 \\
\hline $3 / 4^{\text {th }}-$ ripened & 23.65 & 17.12 & 11.07 & 0.13 & 6.20 & 11.96 & 0.18 & 72.55 \\
\hline Fully ripened & 23.60 & 18.21 & 10.12 & 0.09 & 6.30 & 7.98 & 0.15 & 52.75 \\
\hline S.Em \pm & 0.42 & 0.23 & 0.07 & 0.01 & 0.07 & 0.18 & 0.02 & 2.21 \\
\hline C.D at $1 \%$ & 1.67 & 0.94 & 0.26 & 0.05 & 0.30 & 0.67 & 0.08 & NS \\
\hline
\end{tabular}

\section{CONCLUSION}

From the present study, it is concluded that, physical parameters viz. weight of fruit, peel and pulp, volume of fruit, specific gravity, length and diameter of fruit, fruit colour and chemical parameters viz. TSS. Total and reducing sugars, titratable acidity, $\mathrm{PH}$, ascorbic acid, tannins and moisture of fruits could be considered as maturity indices the potential to extend the shelf of tomato while retaining its nutritional quality.

\section{ACKNOWLEDGEMENTS}

My heart full thank to the Head, Horticulture Department, Faculty of Agriculture, Annamalai University, Tamilnadu, India for providing necessary facilities for carrying out this work.

\section{References}

[1] Anonymous, (1975) Official Methods of analysis, Association of official Analytical Chemistry, Washington, D.C., $12^{\text {th }}$ Edn., pp. $15-18$.

[2] Esteves, M T., Carvalho, M.I.F. de Chitarra, A.B. Chitarra and M.BPaula, (1984). Characteristics of fruits of six guava (Psidium guajava L.) cultivars during ripening. II. Vitamin C and tannins contents. Annal do VII Congreso Brasileiro de Fruitcultura, pp:490 500 .

[3] FAO, (2001), FAO Bulletin of Statistics, Food and Agriculture Organization of the United Nations (FAO). 2: 85

[4] Hulme, A. C., (1970) The Biochemistry of Fruits and Their Products. Academic Press, London and New York Vol. 1. p. 107 and 376.

[5] Joshi, G D., Prabhudesai, V. G. And Salvi, M.J. 1986, Physicochemical characteristic of karonda (Carissa carandas L.) fruits. Maharashtra j. Hort., 3 (1): 39 - 44.

[6] Paralkar, P S., (1985), Studies on physico-chemical changes in sapota(Manilkara achras (mill) Forsberg ) Cv. Kalipatti fruits during growth, development and storage. M.sc. (Agri) Thesis, Dr. Balasaheb Sawant Konkan Krishi Vidyapeeth, Ratnagiri, (India).

[7] Pawar, C. D., (1988), Studies of post-harvest handling and preparation of different products of karonda (Carissa carandas L.) fruits, M.sc. (Agri) Thesis, Dr. Balasaheb Sawant Konkan Krishi Vidyapeeth, Ratnagiri, (India).

[8] Ranganna, S., (1977) Manual of Analysis of Fruit and vegetable Products, Tata Mc. Graw Hill Puplication Company Ltd., New Delhi. Pp. 9-82. 
[9] Raut, V U., (1999), Studies on maturity indices, harvesting, integrated post-harvest handling processing of sapota (Manilkara achras (mill) Forsberg) P.hD. (Agri) Thesis, Dr. Balasaheb Sawant Konkan Krishi Vidyapeeth, Ratnagiri, (India).

[10] Sawant, V S., (1989) Studies on post-harvest handling and preservation of sapota (Manilkara achras (mill) Forsberg) P.hD. (Agri) Thesis, Dr. Balasaheb Sawant Konkan Krishi Vidyapeeth, Ratnagiri, (India).

[11] Suryanarayana, V and Goud, V., (1984), Effect of post-ethrel treatment on ripening of sapota fruits. The Andhra Agric. J., 31 (4): 308 - 311. 